\title{
URGENSI BAHASA ARAB
}

Angga Pandapotan Nasution

Sekolah Tinggi Agama Islam Negeri (STAIN) Papua Barat

Jurusan Dakwah Program Studi Komunikasi Penyiaran Islam

\begin{abstract}
ABSTRAK
Bahasa arab adalah suatu alat komunikasi yang ada di jazirah arab dan asia tengah. Bahasa arab juga merupakan bahasa Al-qur'an yakni kalam Allah SWT dan Hadist, kemahiran bahasa arab ada empat kemahiran yaitu kemahiran istima, berbicara, membaca dan menulis. Dari keempat kemahiran membaca tersebut yang penulis fokuskan dalam penelitian ini adalah kemahiran membaca. Metode pengumpul data yang digunakan adalah tes lisan sebagai metode primer dan sebagai metode sekunder adalah metode observasi, interview dan data dokumentasi
\end{abstract}

\section{Pendahuluan}

Hakikat manusia sebagai makhluk sosial mendorong manusia untuk saling berkomunikasi satu sama lain, berkomunikasi menggunakan bahasa, proses ini terjadi sejak manusia hadir di muka bumi ini Proses ini terjadi sejak manusia hadir dalam kehidupan, sejak itu pula terjadi proses pertukaran ide gagasan keterangan saran usul. Secara umum, bahasa dapat didefinisikan sebagai usaha penyampain pesan antar manusia. Ilmu bahasa tidak mengkaji proses penyampain pesan kepada makhluk yang bukan manusia (hewan dan tumbuh-tumbuhan). Bahasa terjadi dimana saja dan kapan saja. Wilayah bahasa bisa ada dalam makro dan mikro. Mulai dari dua orang, misalnya dalam hubungan "pacaran" antara beberapa orang misalnya dalam keluarga, antar banyak orang ,misalnya dalam suatu kampus atau partai politik. Banyak sekali orang atau melibatkan pihak dalam jumlah yang massif (bahasa massa). Bahasa juga tidak hanya mempelajari pertukaran informasi atau pesan antara dua orang saja, bahasa juga dapat melibatkan banyak orang misalnya kelompok organisasi atau rakyat, bayangkan tanpa bahasa, sejarah peradaban manusia tak akan dapat maju sebagaimana mestinya. 


\section{Pembelajaran Bahasa Arab}

Pembelajaran adalah proses interaksi peserta didik dengan pendidik dan sumber belajar pada suatu lingkungan belajar baik lingkungan pendidikan formal maupun nonformal. Hal ini berarti bahwa pembelajaran merupakan suatu aktifitas yang dilakukan oleh pendidik dan peserta didik pada suatu lingkungan belajar tertentu dengan memanfaatkan sumber-sumber belajar yang relevan dan mengacu pada kurikulum yang berlaku. Sedangkan tujuan pembelajaran bahasa, menurut Basiran (1999) adalah keterampilan komunikasi dalam berbagai konteks komunikasi. Kemampuan yang dikembangkan adalah daya tangkap makna, peran, daya tafsir, menilai, dan mengekspresikan diri dengan berbahasa. Sementara itu, dalam kurikulum 2004 untuk SMA dan MA disebutkan bahwa tujuan pemelajaran (proses, cara, perbuatan mempelajari) bahasa dan Sastra Arab secara umum meliputi: (1) siswa menghargai dan membanggakan Bahasa Arab sebagai bahasa persatuan (nasional) dan bahasa negara, (2) siswa memahami Bahasa Arab dari segi bentuk, makna, dan fungsi,serta menggunakannya dengan tepat dankreatif untuk bermacam-macam tujuan, keperluan, dan keadaan, (3) siswa memiliki kemampuan menggunakan Bahasa Arab untuk meningkatkan kemampuan intelektual, kematangan emosional,dan kematangan sosial,(4) siswa memiliki disiplin dalam berpikir dan berbahasa (berbicara dan menulis), (5) siswa mampu menikmati dan memanfaatkan karya sastra untuk mengembangkan kepribadian, memperluas wawasan kehidupan, serta meningkatkan pengetahuan dan kemampuan berbahasa, dan (6) siswa menghargai dan membanggakan sastra Arab sebagai khazanah budaya dan intelektual manusia Arab.

\section{Pengertian Pendidikan Islam dan Arah Tujuannya}

Untuk memberikan pengertian tentang pendidikan Islam, maka perlu diketahui asal kata tersebut. Kata"pendidikan"adalah terjemahan dari bahasa Arab, yakni Rabba-Yurabbi Tarbiyyatan. Kata tersebut bermakna pendidikan, pengasuhan dan pemeliharaan.Sedangkan definisi Pendidikan Islam secara istilah adalah upaya untuk mengaktualkan sifat-sifat kesempurnaan yang telah dianugerahkan oleh Allah SWT kepada manusia. Upaya tersebut dilaksanakan tanpa pamrih semata-mata beribadah kepada Allah. ${ }^{5}$ Ahli lain juga menyebutkan bahwa pendidikan agama adalah sebagai proses penyampaian informasi dalam rangka pembentukan insan yang beriman dan bertakwa agar manusia menyadari kedudukannya, tugas dan fungsinya di dunia dengan selalu memelihara 
hubungannya dengan Allah, dirinya sendiri, masyarakat dan alam sekitarnya serta tanggung jawab kepada Tuhan Yang Maha Esa (termasuk dirinya sendiri dan lingkungan hidupnya).

Para ahli pendidikan islam telah mencoba memformulasi pengertian pendidikan Islam, di antara batasan yang sangat variatif tersebut adalah: Al-Syaibany mengemukakan bahwa pendidikan agama islam adalah proses mengubah tingkah laku individu peserta didik pada kehidupan pribadi, masyarakat dan alam sekitarnya. Proses tersebut dilakukan dengan cara pendidikan dan pengajaran sebagai sesuatu aktivitas asasi dan profesi di antara sekian banyak profesi asasi dalam masyarakat. Muhammad Fadhil al-Jamaly mendefenisikan pendidikan Islam sebagai upaya pengembangan, mendorong serta mengajak peserta didik hidup lebih dinamis dengan berdasarkan nilai-nilai yang tinggi dan kehidupan yang mulia. Dengan proses tersebut, diharapkan akan terbentuk pribadi peserta didik yang lebih sempurnah, baik yang berkaitan dengan potensi akal, perasaan maupun perbuatanya. Ahmad D. Marimba mengemukakan bahwa pendidikan islam adalah bimbingan atau pimpinan secara sadar oleh pendidik terhadap perkembangan jasmani dan rohani peserta didik menuju terbentuknya kepribadian yang utama (insan kamil). Ahmad Tafsir mendefenisikan pendidikan islam sebagai bimbingan yang diberikan oleh seseorang agar ia berkembang secara maksimal sesuai dengan ajaran Islam.

Dari batasan di atas, penulis dapat menyimpulkan bahwa pendidikan Islam adalah suatu sistem yang memungkinkan seseorang (peserta didik) agar dapat mengarahkan kehidupannya sesuai dengan ideologis atau gaya pandang umat islam selama hidup di dunia. Berdasarkan uraian di atas, maka penulis dapat menyimpulkan bahwa pendidikan agama Islam adalah usaha sadar atau kegiatan yang disengaja dilakukan untuk membimbing sekaligus mengarahkan anak didik menuju terbentuknya pribadi yang utama (insan kamil) berdasarkan nilai-nilai etika islam dengan tetap memelihara hubungan baik terhadap Allah Swt (hablumminallah) sesama manusia (hablumminannas), dirinya sendiri dan alam sekitarnya.

Sedangkan dasar pendidikan Islam sebagai salah satu aspek dari ajaran Islam adalah al-Qur'an dan Hadis Nabi Muhammad SAW. Dari kedua sumber tersebut, para intelektual muslim kemudian mengembangkannya dan mengklasifikannya kedalam dua bagian yaitu: Pertama, akidah untuk ajaran yang berkaitan dengan keimanan. Kedua adalah syariah untuk ajaran yang berkaitan dengan amal nyata. Oleh karena pendidikan 
termasuk amal nyata, maka pendidikan tercakup dalam bidang syariah. Bila diklasifikasikan lebih lanjut, termasuk dalam sub bidang muamalah.

\section{Arah dan Tujuan Pendidikan Islam}

Tujuan pendidikan Islam identik dengan tujuan hidup seorang muslim. Bila pendidikan dipandang sebagai suatu proses, maka proses tersebut akan berakhir pada tercapainya tujuan pendidikan. Suatu tujuan yang hendak dicapai oleh pendidikan pada hakikatnya adalah suatu perwujudan dari nilai-nilai ideal yang terbentuk dalam pribadi manusia yang diinginkan. Nilai-nilai ideal itu mempengaruhi dan mewarnai pola kehidupan manusia, sehingga menggejala dalam perilaku lahiriahnya, dengan kata lain perilaku lahiriah adalah cermin yang memproyeksikan nilai-nilai ideal memacu di dalam jiwa manusia sebagai produk dari proses pendidikan. Pendidikan Islam juga mempunyai tujuan yang sesuai dengan falsafah dan pandangan hidup yang digariskan Alquran. Ibnu Khaldun mengatakan sebagaimana dikatakan oleh Ramayulis bahwa tujuan pendidikan Islam mempunyai dua tujuan. Pertama tujuan keagamaan, maksudnya beramal untuk akhirat, sehingga ia menemui Tuhannya dan telah menunaikan hak-hak Allah yang diwajibkan ke atasnya.Kedua, tujuan ilmiah yang bersifat keduniaan, yaitu apa yang diungkapkanoleh pendidikan modern dengan tujuan kemanfaatan atau persiapan untuk hidup. Demikian pula Abdullah Fayad menyatakan bahwa pendidikan Islam mengarah pada dua tujuan. Pertama, persiapan untuk hidup akhirat. Kedua, membentuk perorangan dengan ilmu pengetahuan dan keterampilanuntuk menunjang kesuksesan hidup di dunia. Semua rumusan tujuan yang dikemukakan di atas sesuai dengan nilai-nilai Islam.

Selanjutnya al-Gazali berpendapat bahwa tujuan pendidikan Islam yang paling utama ialah beribadah dan taqarrub kepada Allah SWT dari kesempurnaan insani yang tujuannya kebahagiaan dunia dan akhirat. Selain dari pandangan yang dikemukakan oleh al-Gazali tentang tujuan pendidikan Islam. Al-Gazali merumuskan tujuan umum pendidikan Islam kedalam lima pokok: (1) Membentuk akhlak yang mulia. (2) Persiapan untuk dunia dan akhirat. (3) Persiapan untuk mencari rezki dan pemeliharaan segi-segi pemanfaatannya. Keterpaduan antara agama dan ilmu akan dapat membawa manusia kepada kesempurnaan. (4) Menumbuhkan ruh ilmiah para pelajar dan memenuhi keinginan untuk mengetahui serta memiliki kesanggupan untuk mengkaji ilmu sekedar sebagai ilmu. (5) Mempersiapkan para pelajar untuk suatu profesi tertentu sehingga ia mudah mencari 
rezki. Sebagaimana diketahui bahwa tujuan pendidikan adalah salah satu faktor determinan dalam pendidikan pada umumnya. Secara khusus dalam pendidikan Islam, yang menjadi tujuan utama adalah terbentuknya akhlak yang mulia. Berbagai aspek yang harus dilihat dalam rangka penetapan dan pemantapan tujuan pendidikan tersebut termasuk pendidikan Islam. Aspek-aspek yang dimaksud adalah berkaitan dengan berbagai hal yang harus diperhatikan dalam hubungannya dengan subjek dan objek didik. Sebagai titik akhir yang ingin dicapai adalah kesempurnaan jiwa manusia. Kesempurnaan jiwa diasumsikan sebagai suatu capaian yang harus diraih oleh segenap usaha manusia. Oleh karenanya perangkat pendidikan yang direkayasa senantiasa mencerminkan daya dukungnya terhadap tujuan itu. Dengan kondisi ideal seperti itu menurut para ahli pendidikan Islam, manusia harus diarahkan ke arah pencapaian kualitas tertentu yang dapat digunakannya dalam kehidupan ini. Berbagai penelitian yang telah dikemukakan untuk mengkaji sekitar tujuan umum pendidikan Islam yang bersumber dari kenyataan-kenyataan serta pemikiran- pemikiran yang berkembang sekitar pendidikan Islam. AR. Nahlawi, menyatakan bahwa tujuan umum pendidikan Islam adalah: (1) meningkatkan kemampuan akal dan menumbuhkan pikiran, (2) menumbuhkan potensi-potensi bakat yang dibawa sejak lahir, (3) mengembangkan potensi generasi muda, dan (4) menjaga keseimbangan potensi dan bakat manusia. Akal merupakan anugrah pemberian Tuhan yang dikhususkan kepada manusia sebagai jenis makhluk yang mengembang tugas berat dan mulia. Oleh karena pengembangan akal manusia harus menjadi prioritas dalam tujuan pendidikan.

- Pembelajaran adalah proses interaksi peserta didik dengan pendidik dan sumber belajar pada suatu lingkungan belajar baik lingkungan pendidikan formal maupun nonformal.

- Sebagai suatu alat pendidikan dapat difungsikan untuk mengarahkan pertumbuhan dan perkembangan hidup manusia kepada titik optimal kemampuannya untuk kesejahteraan dan kebahagiaan hidupnya di akhirat.

- Tujuan pendidikan Islam identik dengan tujuan hidup seorang muslim. Bila pendidikan dipandang sebagai suatu proses, maka proses tersebut akan berakhir pada tercapainya tujuan pendidikan. 


\section{DAFTAR PUSTAKA}

Al-Ansori, Fauzan, Melawan Konspirasi JIL, Jakarta:Pustaka al-Furqan, 2003.

Ali, Daud, Pendidikan Agama Islam, Jakarta: Rajawali Press, 1995.

Al-Jumbulati, Ali, Perbandingan Pendidikan Islam, Bandung: Rineka Cipta, 2013.

Anis, Ibrahim, Fi al-Lahaja>t al-'Arabiyah, Mesir: Maktabah al-Anjlu, 1965.

Arsyad, Azhar, Bahasa Arab dan Metode Pengajarannya, Yogyakarta: Pustaka Pelajar, 2003.

Bawani, Imam, Cendikiawan Muslim dalam Perspektif Pendidikan Islam, Surabaya: Bina Ilmu, 1991.

Chejne, Anwar G., Bahasa Arab dan Peranannya dalam Sejarah, terj. Aliudin Mahjudin, Jakarta: Pusat Pembinaan dan Pengembangan Bahasa, 1996.

Depertemen Agama RI, Al-Quran dan Terjemahannya, Semarang: Thoha Putra, 1989. 